\title{
Stiffness and Strength Analysis of Flexural RC beams strengthened with CFRP Sheets Considering the Influence of Pre-cracking
}

\author{
Tadas LISAUSKAS*, Mindaugas AUGONIS**, Tadas ZINGAILA***, \\ Mario Rui Tiago ARRUDA**** \\ *Kaunas University of Technology, Faculty of Civil Engineering and Architecture, Studentu st. 48, LT-51367 Kaunas, \\ Lithuania, E-mail tadaslisauskas@gmail.com \\ **Kaunas University of Technology, Faculty of Civil Engineering and Architecture, Studentu st. 48, LT-51367 Kaunas, \\ Lithuania, E-mail: mindaugas.augonis@ktu.lt \\ ***Kaunas University of Technology, Faculty of Civil Engineering and Architecture, Studentu st. 48, LT-51367 Kaunas, \\ Lithuania, E-mail: tadas.zingaila@ktu.lt \\ ****CERIS, Instituto Superior Técnico, Universidade de Lisboa, Department of Civil Engineering and Architecture, Av. \\ Rovisco Pais, 1049-001 Lisboa, E-mail: mario.rui.arruda@tecnico.ulisbao.pt
}

cross $^{\text {ref }}$ http://dx.doi.org/10.5755/j01.mech.26.4.25064

\section{Introduction}

Nowadays in modern world, when architecture is getting more complex and the structural requirements are growing higher, the strengthening of structures plays an important role. Carbon fibre reinforced polymer (CFRP) is a perspective material for strengthening of reinforced concrete (RC) beams. CFRP has a very high strength and great corrosion resistance. Curved beams are much easier to reinforce with CFRP sheets than with solid steel plates, due to much lower stiffness of CFRP sheets in comparison to steel plates. The efficiency of CFRP for strengthening of flexural RC beams with CFRP has been studied by many authors [19]. However, there are not enough investigations made directly on experimental, analytical and numerical analysis of pre-cracked RC structures strengthened with CFRP [10 12]. There is also relatively high price of CFRP, as well as it is difficult to predict the level of concrete damage. Due to those reasons numerical and analytical calculation models of highly damaged composite flexural members must be fully analysed, reliable to use, and to be as simple as possible for practical application. For this purpose, many researches must be carried out for clear understanding of the structural behaviour of composite members. Contribution to this topic is very important from all the scientists.

The strengthening of CFRP is very important for the improvement of structural properties. Application of CFRP enhances flexural capacity, increases stiffness, reduces crack widths and spacing [11].

Numerical analysis of RC beams strengthening with CFRP can be found in scientific papers [13], [14]. Comparison of numerical and experimental results showed that finite element (FE) method can quite accurately predict the structural behaviour of RC flexural members strengthened with CFRP. The parameters of contact zone between CFRP and concrete are very important for strength. Many authors describe significantly different values of bond strength [13], [15-20]. The variation of parameter values can be very high. This states that the type of resin and the roughness of the concrete surface are important. The stiffness of connection makes significant influence on final stiffness of composite beam.
This paper is intended to show a comparative analysis of experimental and numerical methods. The main objective of this paper is to evaluate the influence of different stages of cracks and damage on strength and stiffness of RC beams strengthened with CFRP. The stiffness analysis of the experimental (according to linear displacement sensors and dial gauges), numerical (ABAQUS) and analytical (layers) methods are provided.

\section{Experimental investigation}

\subsection{Test programme}

In this research, the experimental tests were carried out on purpose to determine the strength of uncracked and cracked beams, deflections and slip between concrete and CFRP sheets. In total, nine composite beams strengthened with CFRP were tested using four-point bending scheme. The arrangement of the beam bending experiment is presented in Fig. 1.

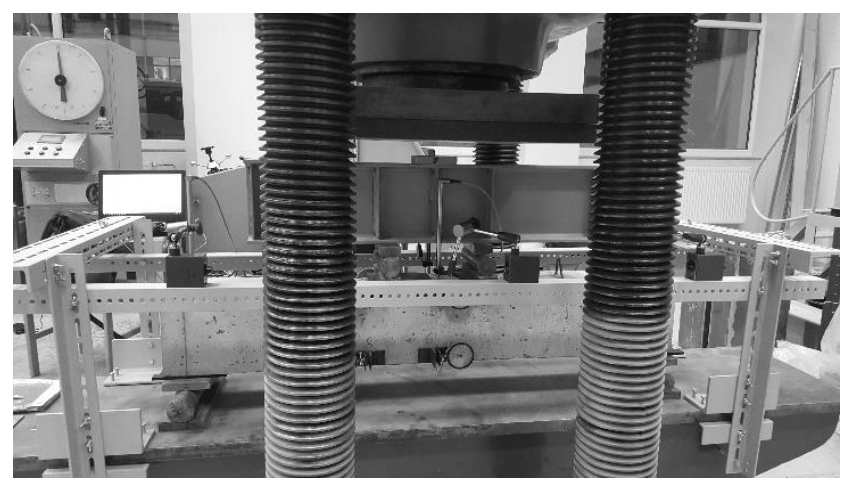

Fig. 1 Test setup of reinforced concrete beam strengthened with CFRP

\subsection{Properties of the materials}

Main mechanical properties of concrete with $95 \%$ reliability are given in Table 1 . The strength and secant modulus of elasticity of concrete were obtained from the compression tests (cubes $-100 \times 100 \times 100 \mathrm{~mm}$ and prisms $300 \times 100 \times 100 \mathrm{~mm})$. 
Table 1 at the mid-span) were used to measure deflections of the

Mechanical properties of concrete

\begin{tabular}{|c|c|c|c|c|}
\hline $\begin{array}{c}\text { Con- } \\
\text { crete se- } \\
\text { ries } \\
\text { (casting) }\end{array}$ & $\begin{array}{c}\text { Quantity } \\
\text { of } \\
\text { cubic } \\
\text { speci- } \\
\text { mens, pcs }\end{array}$ & $\begin{array}{c}\text { Compres- } \\
\text { sion } \\
\text { strength, } \\
f_{c, \text { cube, }} \\
\text { MPa }\end{array}$ & $\begin{array}{c}\text { Quantity } \\
\text { of } \\
\text { prism } \\
\text { speci- } \\
\text { mens, pcs }\end{array}$ & $\begin{array}{c}\text { Secant } \\
\text { modulus } \\
\text { of elas- } \\
\text { ticity, } \\
E_{c m}, \text { GPa }\end{array}$ \\
\hline 1 & 12 & $57.0 \pm 3.3$ & 3 & $40.5 \pm 3.2$ \\
\hline 2 & 20 & $61.4 \pm 5.8$ & 4 & $45.0 \pm 2.5$ \\
\hline 3 & 18 & $53.0 \pm 2.8$ & 4 & $37.6 \pm 2.2$ \\
\hline
\end{tabular}

The mechanical properties [21] of CFRP and adhesive resin are given in Table 2.

Table 2

Mechanical properties of CFRP and resin

\begin{tabular}{|c|c|c|c|}
\hline Materials & $\begin{array}{c}\text { Thickness } \\
t, \mathrm{~mm}\end{array}$ & $\begin{array}{c}\text { Tensile } \\
\text { strength } \\
f_{u}, \mathrm{MPa}\end{array}$ & $\begin{array}{c}\text { Modulus of } \\
\text { elasticity } \\
E, \mathrm{GPa}\end{array}$ \\
\hline Drizoro $^{\circledR}$ wrap 300 & 0.167 & 3400 & 230 \\
\hline Maxepox-CS $^{2}$ & 0.727 & 29 & 1.5 \\
\hline
\end{tabular}

All beams were reinforced with the same amount of reinforcement. The longitudinal reinforcement $\varnothing 12 \mathrm{~mm}$ and the transverse reinforcement $\varnothing 6 \mathrm{~mm}$. The range of yield strength of B500B rebars is between $555 \mathrm{MPa}-624 \mathrm{MPa}$ [22-27]. In this case, it was assumed that yield strength of rebars is $f_{y}=600 \mathrm{MPa}$, ultimate tensile strength according to [28] $f_{u}=648 \mathrm{MPa}$. Modulus of elasticity $E_{s}=200 \mathrm{GPa}$ [28].

\subsection{Specimens and test setup}

Nine beams have been tested under four-point bending during the experimental programme. All beams were the same $1.3 \mathrm{~m}$ length. However, there were three series of different type strengthening with carbon fibre, positioned symmetrically on the bottom surface of the beam. 1 - beams strengthened with one-layer of CFRP (length 0.7 $\mathrm{m}) ; 2$ - beams strengthened with three layers of CFRP (length $1.0 \mathrm{~m}$ ); 3 - beams strengthened with one layer of CFRP (length $1.0 \mathrm{~m}$ ). Each of 1, 2, 3 series beams had three types of cracks: A - beams without initial cracks; B - beams with initial cracks of $0.4 \mathrm{~mm}$ (primary load before strengthening $-60 \mathrm{kN}$ ); $\mathrm{C}$ - beams with initial cracks (primary load before strengthening $\sim 95 \mathrm{kN}$, when rebars of beams reached yield strength). The initial cracks mean that the reinforced concrete beam was loaded with $60(95) \mathrm{kN}$ vertical force and then unloaded. After that the CFRP sheet was glued and the beam was loaded one more time (beams had additional cracks).

Amount of used CFRP sheets and initial cracking state of strengthened $\mathrm{RC}$ beams is presented in Table 3 . The initial crack widths of unloaded RC beams before strengthening and the distribution of initial cracks over RC beams length are presented in Table 4 and Fig. 2.

Cross-sections of specimens and load scheme are presented in Fig. 3. The arrangement of the beam bending experiment is presented in Fig. 3. The dial gauges were installed to measure the strains of concrete in compression and tension zones (six were fixed in pure bending moment zone and two in shear zone). According to measured strains, the curvatures for all beams were calculated. Four linear displacement sensors (two were fixed at the supports and two beams. The strain gauges were installed to measure strains of concrete and CFRP. According to the measured difference of strains between CFRP and concrete, the slip of CFRP was calculated. Also, the strain of concrete and CFRP was measured on both ends of CFRP sheet, due to the reason that it is not clear which end will lose the bond first. The arrangement of strain gauges is presented in Fig. 4.

Table 3

Amount of CFRP sheets and cracking state of strengthened $\mathrm{RC}$ beams

\begin{tabular}{|c|c|c|c|}
\hline $\begin{array}{c}\text { Beam } \\
\text { type }\end{array}$ & $\begin{array}{l}\text { The number of } \\
\text { CFRP layers }\end{array}$ & $\begin{array}{l}\text { The length of } \\
\text { CFRP } l, m\end{array}$ & $\begin{array}{c}\text { Initial cracks } \\
\text { width of loaded } \\
\text { RC beam } w, \mathrm{~mm}\end{array}$ \\
\hline A1 & 1 & 0.7 & Without \\
\hline B1 & 1 & 0.7 & 0.4 \\
\hline $\mathrm{C} 1$ & 1 & 0.7 & $\begin{array}{l}\text { Rebars reached } \\
\text { yield strength }\end{array}$ \\
\hline $\mathrm{A} 2$ & 3 & 1.0 & Without \\
\hline $\mathrm{B} 2$ & 3 & 1.0 & 0.4 \\
\hline $\mathrm{C} 2$ & 3 & 1.0 & $\begin{array}{l}\text { Rebars reached } \\
\text { yield strength }\end{array}$ \\
\hline A3 & 1 & 1.0 & Without \\
\hline B3 & 1 & 1.0 & 0.4 \\
\hline $\mathrm{C} 3$ & 1 & 1.0 & $\begin{array}{l}\text { Rebars reached } \\
\text { yield strength }\end{array}$ \\
\hline
\end{tabular}

Table 4

Initial crack widths of unloaded RC beams before strengthening

\begin{tabular}{|c|c|c|c|}
\hline \multirow{2}{*}{ Beam type } & \multicolumn{3}{|c|}{ Initial crack widths of unloaded beams $w, \mathrm{~mm}$} \\
\cline { 2 - 4 } & $\mathrm{a}$ & $\mathrm{b}$ & $\mathrm{c}$ \\
\hline B1 & 0.025 & 0.05 & 0.025 \\
\hline C1 & 0.1 & 0.8 & 0.1 \\
\hline B2 & 0.05 & 0.05 & 0.05 \\
\hline C2 & 0.03 & 0.9 & 0.7 \\
\hline B3 & 0.05 & 0.1 & 0.05 \\
\hline C3 & 0.2 & 1.0 & 0.4 \\
\hline
\end{tabular}

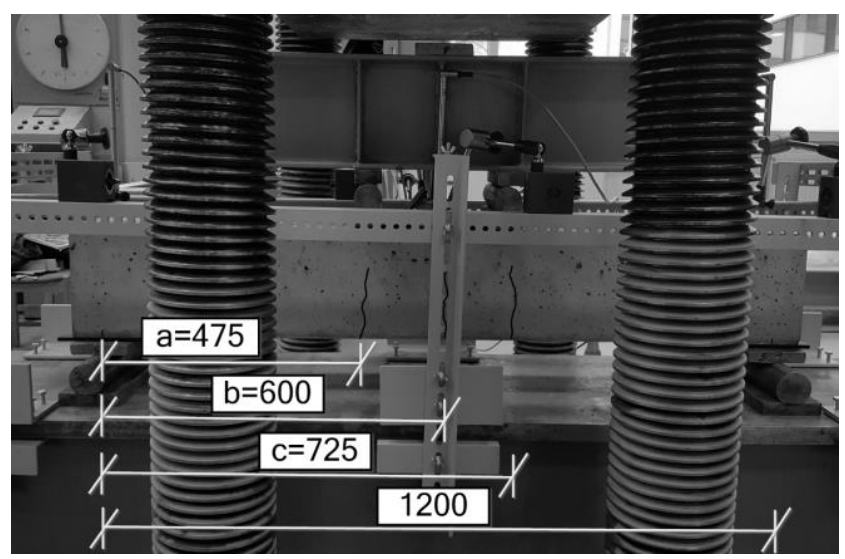

Fig. 2 The distribution of initial cracks over RC beam length

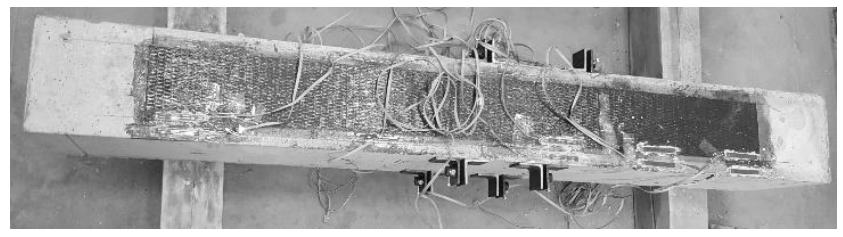

Fig. 4 Arrangement of strain gauges installed on concrete and CFRP 


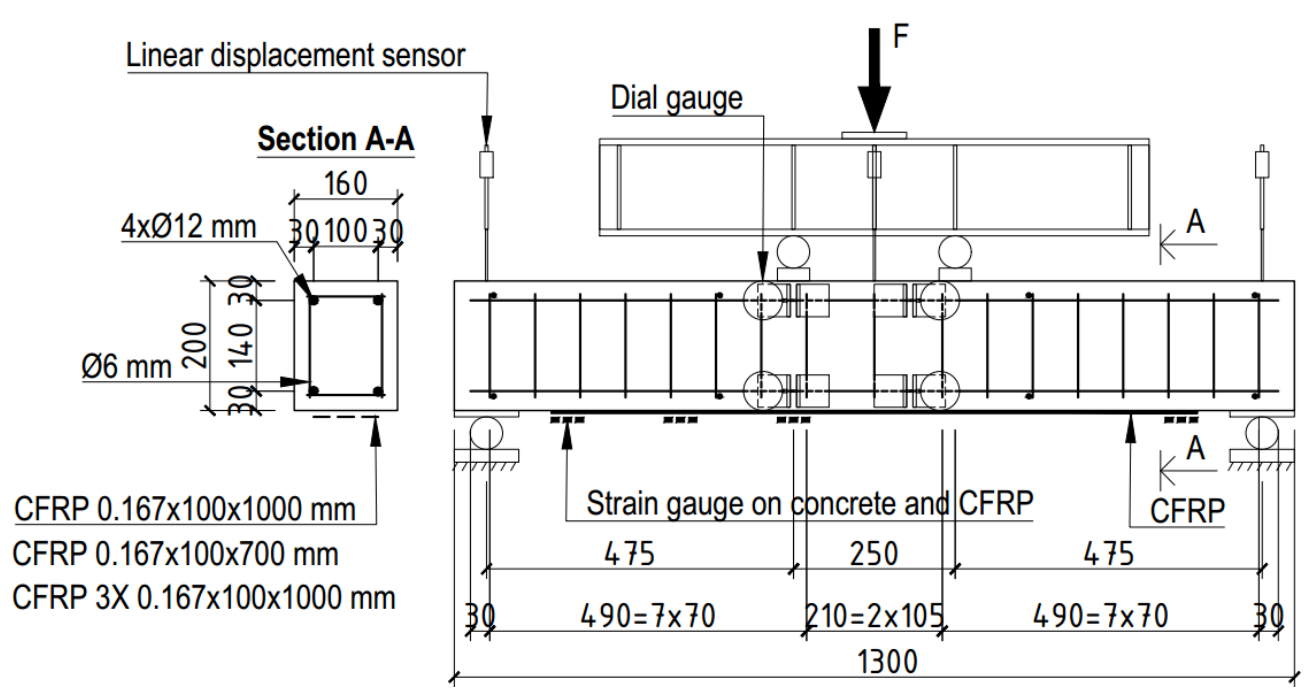

Fig. 3 Test setup and details of composite beams

\section{Numerical investigations}

\subsection{The description of FE model}

Numerical analysis of tested beams was carried out using FE software ABAQUS, in which a physically non-linear analysis was taken into account modelling the concrete. This software has been tested with ordinary reinforced concrete (RC) structures strengthened with CFRP [13-14].

Three-dimensional model was created for composite beams numerical analysis. Parts of the assembly like beam (concrete), support plate and load plate were created as a deformable solid body. Rebars (longitudinal and transverse) were created as wire elements and CFRP - as a shell planar element. The reinforcement was embedded in concrete. Perfect bond between steel and concrete was assumed. Fully constrained contact behaviour was defined using the tie constraints. The size of FE model mesh is presented in Fig. 5. Finite element size of concrete $-10 \mathrm{~mm}$; CFRP $16,6 \mathrm{~mm}$; rebars $-20 \mathrm{~mm}$.

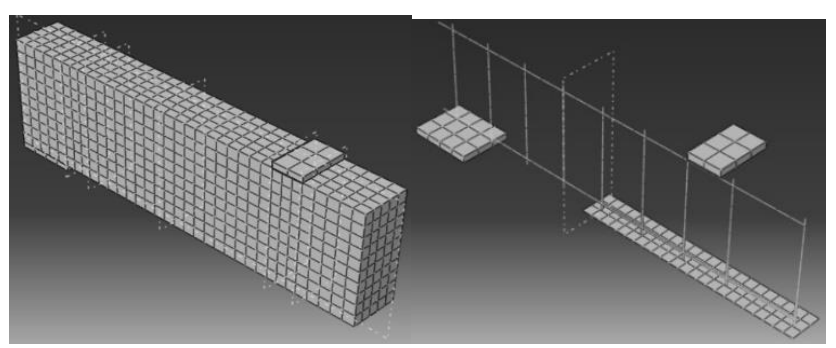

Fig. 5 The size of FE model mesh

The bond between concrete and CFRP was defined as surface to surface contact. Interaction properties - normal behaviour, cohesive behaviour and damage. Pressure-overclosure - "hard" contact, eligible slave nodes - only slave nodes initially in contact. The other properties of contact are presented in Table 5. The stiffness of bond is used as a relation between modulus of elasticity of resin and thickness of resin $E / t$ [13]. The stiffness parameters of the bond are varying in a wide range, but the biggest difference of results $6.2 \%$ between maximum and minimum values (Table 5).

All beams were loaded by displacement control in a vertical direction. In order to reduce the computational cost, a symmetrical analysis was performed, in both longitudinal and transversal axes. The pre-cracked RC beams were created in three steps. First step - RC beam was loaded by respective load, second step - RC beam was unloaded, third step - the bond between concrete and CFRP was activated and the beam was loaded again. It is not possible to evaluate the exact residual stress in this model. The issue of second step is residual plastic deformations of concrete. The plastic deformations of concrete are a reason of huge stresses in steel rebars which do not represent the real situation.

Table 5

Parameters of contact

\begin{tabular}{|l|c|c|}
\hline \multicolumn{1}{|c|}{ Contact properties } & $\begin{array}{c}\text { Value } \\
\text { accepted } \\
\text { in FE } \\
\text { model }\end{array}$ & $\begin{array}{c}\text { Range of } \\
\text { values } \\
\text { from other } \\
\text { authors }\end{array}$ \\
\hline Normal stiffness, $K_{n n} \mathrm{MPa} / \mathrm{mm}$ & 2063 & $16.5-12800$ \\
\hline Shear stiffness, $K_{t t} \mathrm{MPa} / \mathrm{mm}$ & 2063 & $0.41-2900$ \\
\hline Max nominal (shear) stress MPa & 25 & $0.21-25$ \\
\hline Total/Plastic displacement $\mathrm{S}_{L O} \mathrm{~mm}$ & 1.0 & $0.127-1.0$ \\
\hline Viscosity coefficient & 0.001 & 0.001 \\
\hline
\end{tabular}

\subsection{Material models}

Nonlinear model [29] [28] was chosen for modelling compression concrete. This model describes compressive plasticity. Stress-strain relation of compressive concrete is presented in Fig. 6. and can be described using Eq. (1) [29], [28].

$$
\frac{\sigma_{c}}{f_{c m}}=\frac{k \eta-\eta^{2}}{1+(k-2) \eta} \text { for }\left|\varepsilon_{c}\right|<\left|\varepsilon_{c u 1}\right|,
$$

where: $k=1.05 E_{c m}\left|\varepsilon_{c 1}\right| / f_{c m} ; \quad \eta=\varepsilon_{c} / \varepsilon_{c 1} ; \sigma_{c}$ is compressive stress in the concrete; $f_{c m}$ is mean value of concrete cylinder compressive strength; $\varepsilon_{c}$ is compressive strain in the concrete; $\varepsilon_{c u 1}$ is ultimate compressive strain in the concrete; $\varepsilon_{c 1}$ is compressive strain in the concrete at the peak stress; $E_{c m}$ is secant modulus of elasticity of concrete.

Until the crack opens, the linear stress-stain relation was used for tensile concrete. Post-failure tensile stresscrack relation was used as tensile concrete model. Stresscrack curve is presented in Fig. 7 [28]. 


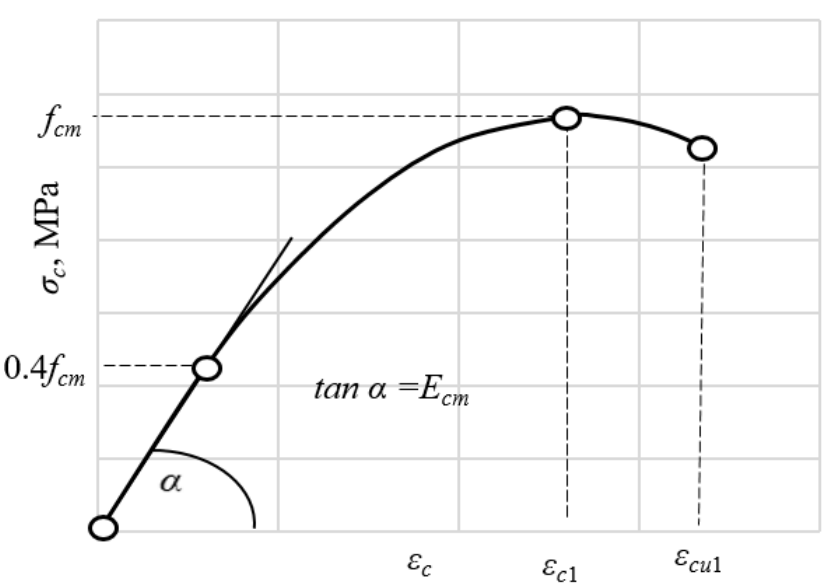

Fig. 6 Stress-strain relation of compressive concrete

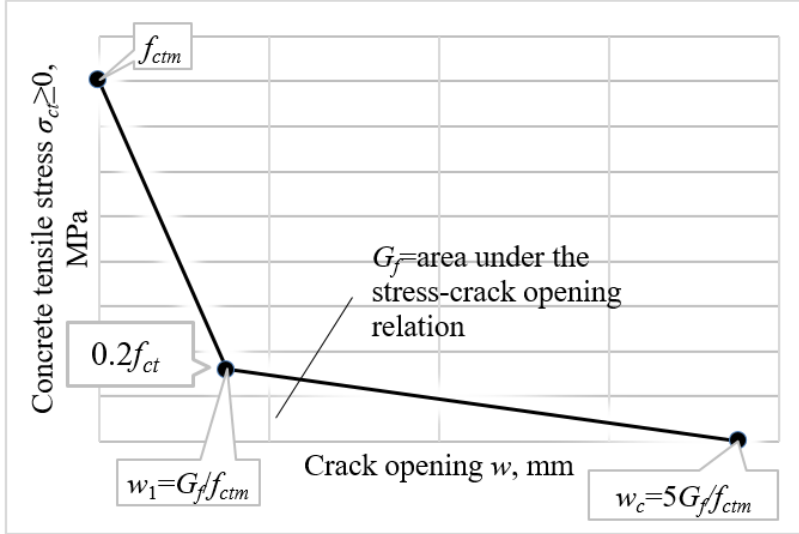

Fig. 7 Stress-crack relation of tensile concrete

Where $w$ is crack width in mm; $G_{F}=73 f_{c m}^{0.18} ; f_{c t m}$ is mean value of axial tensile strength of concrete.

Properties of reinforcement was described as bilinear stress-strain relation Fig. 8.

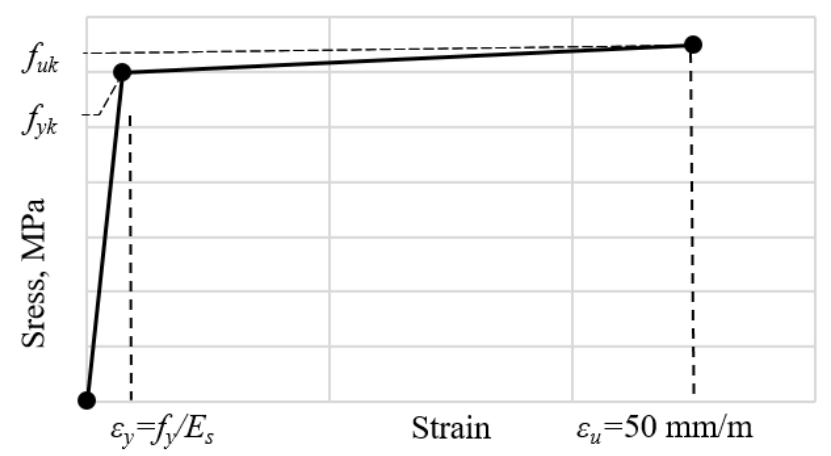

Fig. 8 Stress-strain relation of tensile steel rebars

$$
[E]=\left[\begin{array}{cccccc}
1 & -2 & 1 & 0 & \ldots & 0 \\
0 & 1 & -2 & 1 & \ldots & 0 \\
0 & 0 & 1 & -2 & \ldots & 0 \\
0 & 0 & 0 & 1 & \ldots & 1 \\
E_{1} A_{1} & E_{2} A_{2} & E_{3} A_{3} & E_{4} A_{4} & \ldots & E_{n} A_{n} \\
0 & E_{2} A_{2} h_{i} & E_{3} A_{3} h_{i} & E_{4} A_{4} h_{i} & \ldots & (1-n) E_{n} A_{n} h_{i}
\end{array}\right]
$$

\section{Analytical investigations}

Analytical analysis of tested beams was carried out using layers method [30]. Physically non-linear analysis was considered for calculation of concrete stress and strains in each layer (Fig. 9). At the beginning in all layers Hooke's law is valid. After the first iteration the relative strains of every layer were recalculated. If the relative strains exceeded the elastic limit of this layer, then the elasticity modulus of this layer was reduced. When the relative strains exceeded the ultimate strains, then the deformation modulus of this layer was set to 0 . Sufficiently precise strains were received after calculating a several of iterations. According to the calculated strains of layers and the deformation modulus it was possible to easily calculate the stress. The general case can be described using Eq. (2).

$$
[E]\{\boldsymbol{\varepsilon}\}=\{\mathbf{F}\},
$$

where: $[E]$ - matrix of stiffness $(6) ;\{\boldsymbol{\varepsilon}\}$ - vector of deformation (3); $\{\mathbf{F}\}$ - vector of forces (4).

$$
\{\varepsilon\}=\left\{\begin{array}{llllll}
\varepsilon_{1} & \varepsilon_{2} & \varepsilon_{3} & \varepsilon_{4} & \ldots & \varepsilon_{n}
\end{array}\right\}^{T},
$$

where: $\boldsymbol{\varepsilon}_{\mathbf{i}}$ is relative deformation of $i$ layer.

$$
\{\mathbf{F}\}=\left\{\begin{array}{llllll}
0 & 0 & 0 & 0 & \ldots & \mathbf{M}
\end{array}\right\}^{T},
$$

where: $\mathbf{M}$ is bending moment. to Eq. (5).

The deflection of the beam is calculated according

$$
f=k l^{2} \frac{1}{r}
$$

where: $k=0.0989$ is coefficient according calculation scheme; $l$ is length of beam span; $1 / r$ is curvature $\left(1 / r=\left(\varepsilon_{1}-\varepsilon_{\mathbf{n}}\right) / h\right) ; h$ is height of beam.

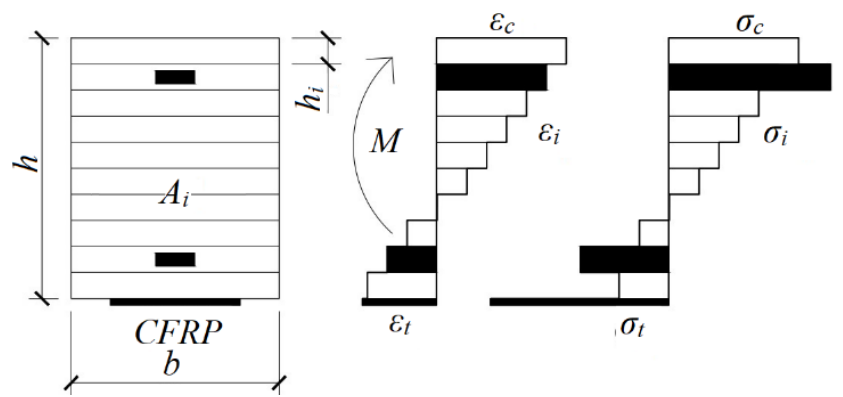

Fig. 9 Dividing of flexural element into layers

Fig. where: $E_{i}$ is deformation modulus of $i$ layer; $A_{i}$ is area of cross-section of $i$ layer. 


\section{Results}

The ultimate failure forces of composite beams obtained from experimental results are presented in Table 6 . The biggest load-bearing capacity was reached by $\mathrm{C}$ series beams. It means that the biggest flexural capacity had those beams which were strengthened with CFRP after preloading (with initial cracks). This could have happened because of debonding of CFRP sheets before the rebars reached the yield strength. Concrete in $\mathrm{B}$ and $\mathrm{C}$ series of composite beams had an elastic-plastic deformation after the unloading [31]. It means that the steel rebars had residual stresses. Predeflections of composite beams are presented in Table 7. B and $\mathrm{C}$ series beams strengthened with CFRP reached the same shear stress between the concrete and CFRP with higher stress of the rebars in comparison to A series. The same bond strength between concrete and CFRP, as well as higher stress of rebars influence on bigger flexural capacity of composite beam.

Table 6

Ultimate failure forces of composite beams

\begin{tabular}{|c|c|c|c|}
\hline Failure force $F, \mathrm{kN}$ & 1 series & 2 series & 3 series \\
\hline A series & 110.2 & 103.7 & 120.9 \\
\hline B series & 116.2 & 127.3 & 124.1 \\
\hline C series & 117.6 & 138.2 & 133.0 \\
\hline
\end{tabular}

Table 7

Pre-deflections of composite beams

\begin{tabular}{|c|c|c|c|}
\hline Pre-deflection $f_{R s}, \mathrm{~mm}$ & 1 series & 2 series & 3 series \\
\hline B series & 1.03 & 0.40 & 0.43 \\
\hline C series & 1.52 & 3.00 & 3.12 \\
\hline
\end{tabular}

Another reason of bigger resistance of $\mathrm{B}$ and $\mathrm{C}$ series specimens could be the curvature (deflection). Bigger deflection influence on higher transversal forces at the ends of CFRP sheets. In Figs. 10-12 load-deflection curve is presented. A1-3, B1-3, C1-3 are the curves of composite beams after strengthening with CFRP. B1-3, C1-3 pre-deflections are curves of strengthened beams evaluating pre-deflections.

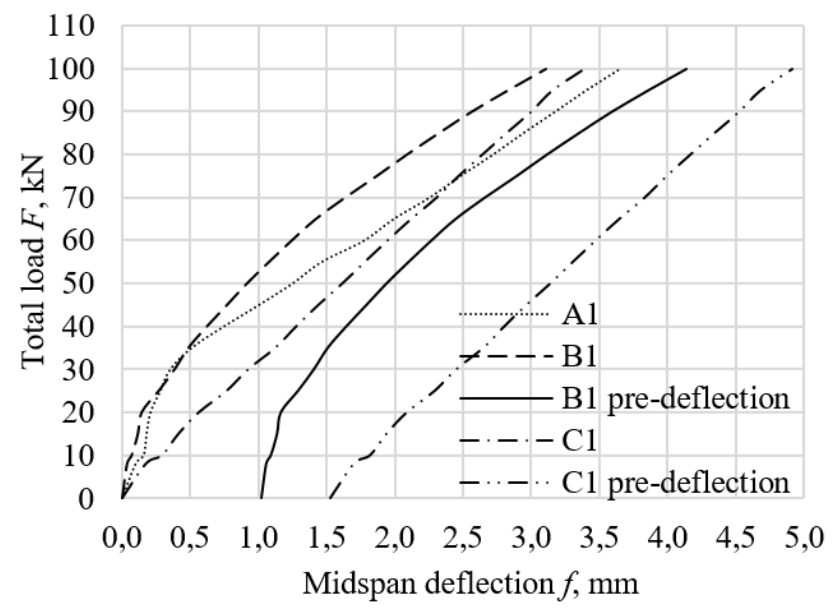

Fig. 10 Load-deflection curve of 1 series

The deflections of A series beams are smaller compared with $B$ and $C$ series until $25-45 \mathrm{kN}$. At that moment beams reached the critical cracking moment and the deflec- tion started to increase faster. When the beams reached approximately $50-80 \mathrm{kN}$ load, the deflection of A series became higher than the deflection of $\mathrm{B}$ and $\mathrm{C}$ series beams. Figs. 10-12 presents load-deflection curves in which are evaluated pre-deflections. The biggest deflection taking into account pre-deflection was observed in $\mathrm{C}$ series beams.

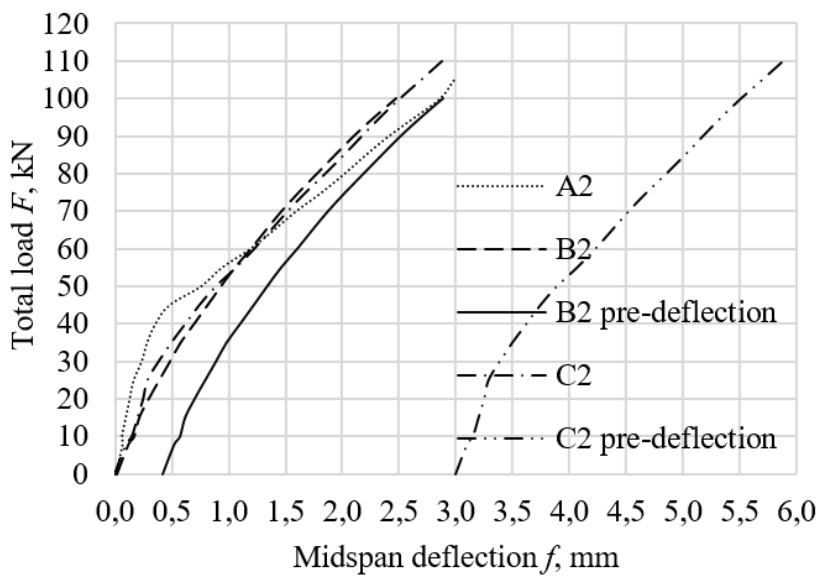

Fig. 11 Load-deflection curve of 2 series

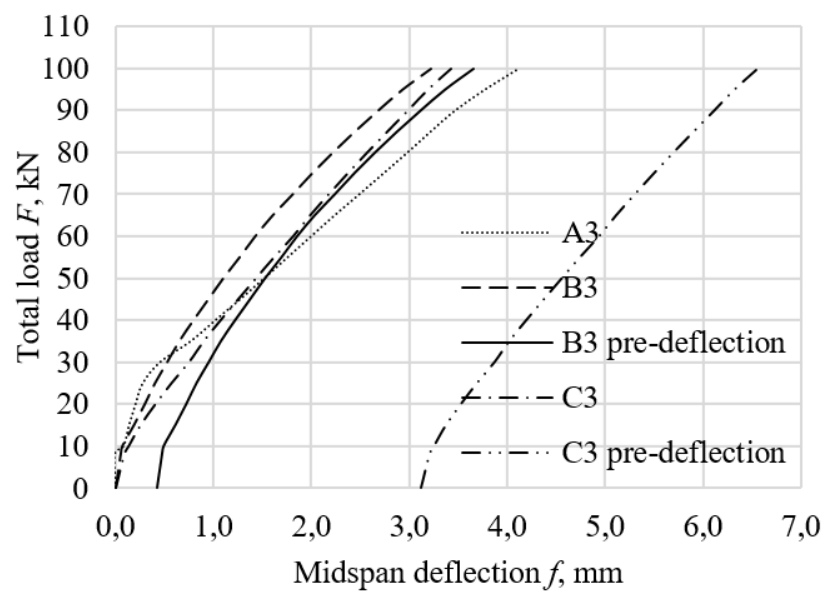

Fig. 12 Load-deflection curve of 3 series

Load-deflection curves of A series are presented in Fig. 13-15. Analytical and numerical results are compared with experimental results. The distribution of cracks over the length of A series beams are presented in Fig. 16. The number from 1 to 8 defines positioning of dial gauges in tension or compression zone. The strains of concrete are measured in shear and normal cracks, as well as in uncracked zones. The types of zones are presented in Table 8 . Most of dial gauges in tension zone were installed on the cracks. The calculations are carried out according to EC2 [29]. The curvature of the uncracked zone is calculated according to the equation $1 / r=M / E I$, curvature of the cracked zone is calculated according to the results measured by dial gauges.

Table 8

Type of dial gauges measuring zone

\begin{tabular}{|c|c|c|c|c|}
\hline Dial gauge No. & $1-2$ & $3-4$ & $5-6$ & $7-8$ \\
\hline A1 series & $\begin{array}{c}\text { Uncracked } \\
\text { Szone }\end{array}$ & $\begin{array}{c}\text { Uncracke } \\
\text { d Bzone }\end{array}$ & $\begin{array}{c}\text { Cracked } \\
\text { Bzone }\end{array}$ & $\begin{array}{c}\text { Cracked } \\
\text { Bzone }\end{array}$ \\
\hline A2 series & $\begin{array}{c}\text { Cracked } \\
\text { Szone }\end{array}$ & $\begin{array}{c}\text { Cracked } \\
\text { Bzone }\end{array}$ & $\begin{array}{c}\text { Cracked } \\
\text { Bzone }\end{array}$ & $\begin{array}{c}\text { Cracked } \\
\text { Bzone }\end{array}$ \\
\hline A3 series & $\begin{array}{c}\text { Cracked } \\
\text { Bzone }\end{array}$ & - & $\begin{array}{c}\text { Cracked } \\
\text { Bzone }\end{array}$ & $\begin{array}{c}\text { Uncracke } \\
\text { d Szone }\end{array}$ \\
\hline
\end{tabular}

where: Bzone - bending zone; Szone - shear zone 


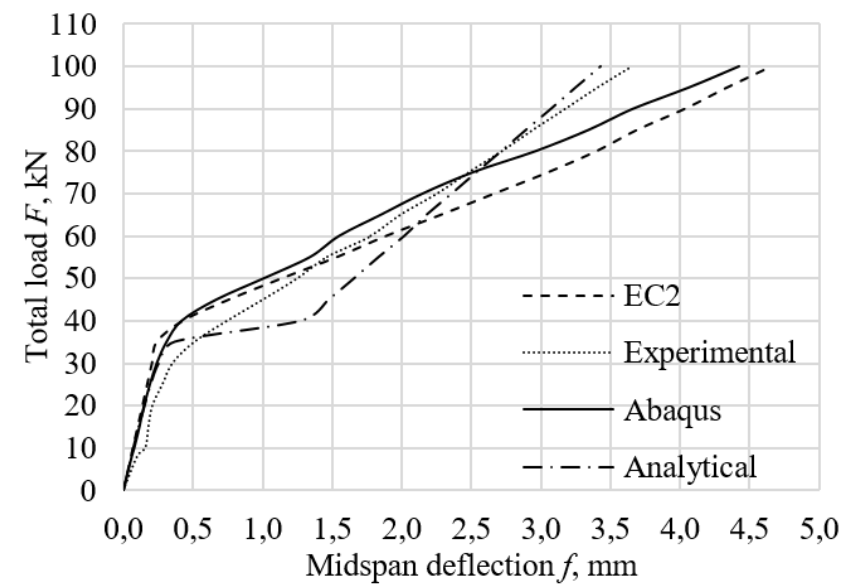

Fig. 13 Load-deflection curve of A1 series

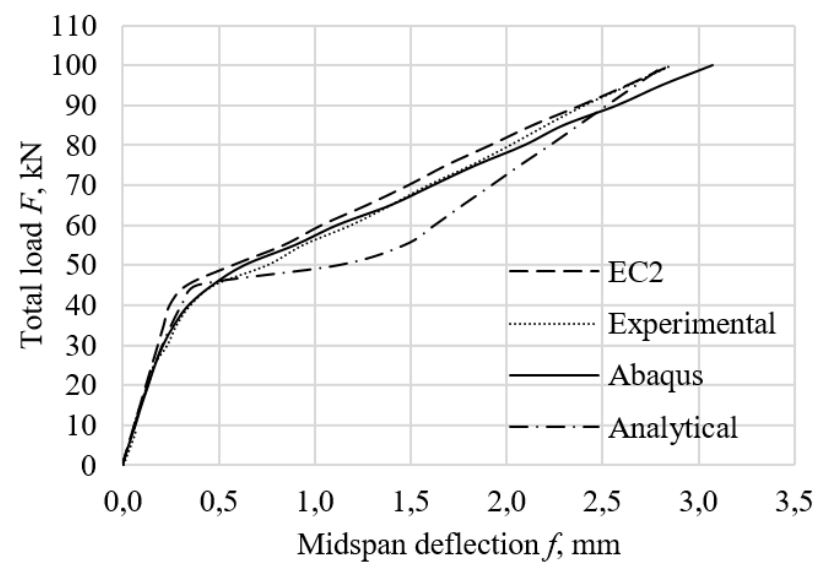

Fig. 14 Load-deflection curve of A2 series

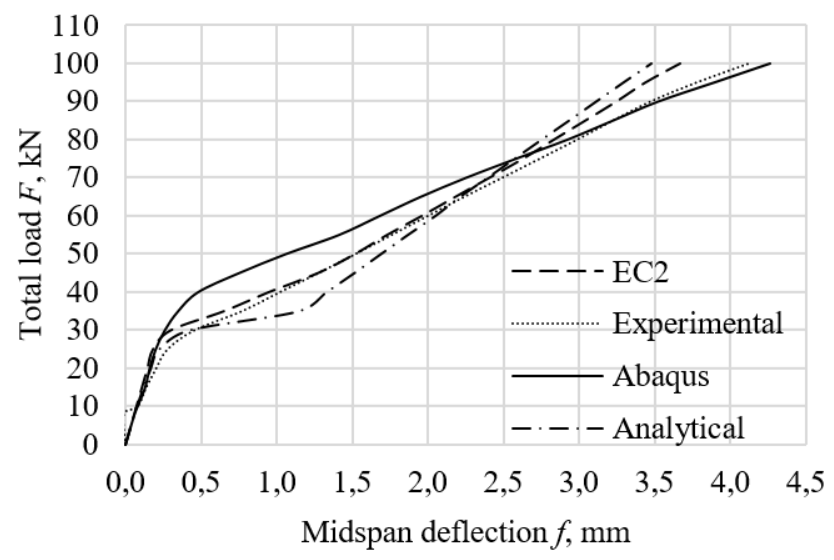

Fig. 15 Load-deflection curve of A3 series

The experimental and the numerical results of the beams are obtained similar, however the stiffness of numerical beams is lower than experimental. The stiffness of composite beams calculated by analytical method is higher in comparison to experimental, however significant decrease of stiffness is reached after the initial cracks. The experimental deflections are very similar to deflections which are calculated according to EC2 methodology, except the A1 series beam, where stiffness is slightly decreased in comparison to the experimental. The stiffness of the RC beams strengthened with CFRP can be calculated according to EC2.

Experimental and calculated results of crack widths are presented in Figs. 17-19. In almost all the cases, the EC2 gives higher values of crack widths. The highest difference of crack width was $41.0 \%$ in a beam A2. The smallest difference between experimental and $\mathrm{EC} 2$ results was from $0 \%$ to $17.9 \%$, approximately at $55 \mathrm{kN}$ in A series beam.

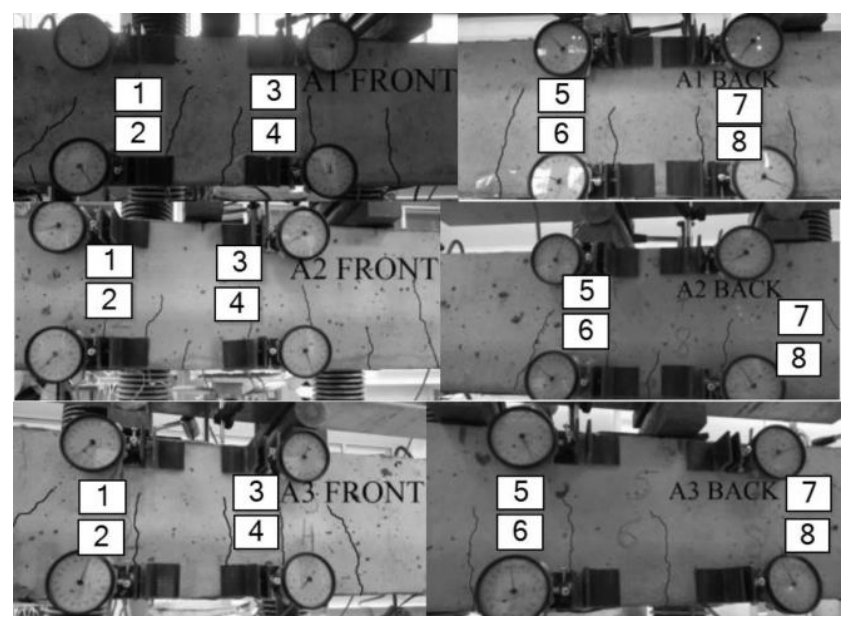

Fig. 16 The cracks distribution of A series beams

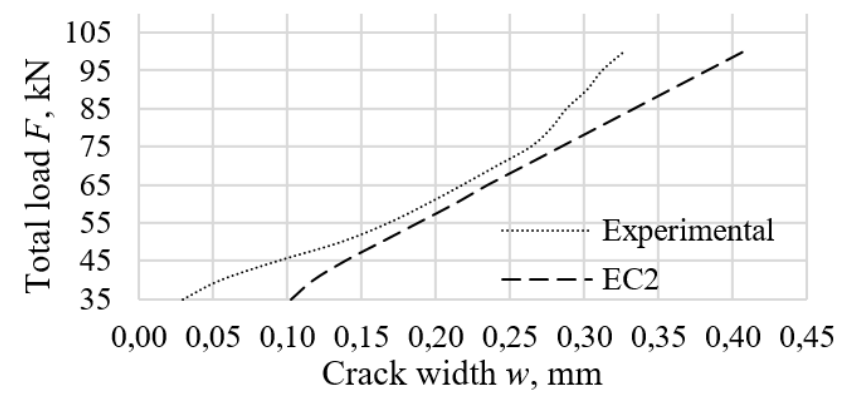

Fig. 17 Load-crack width curve of A1 series

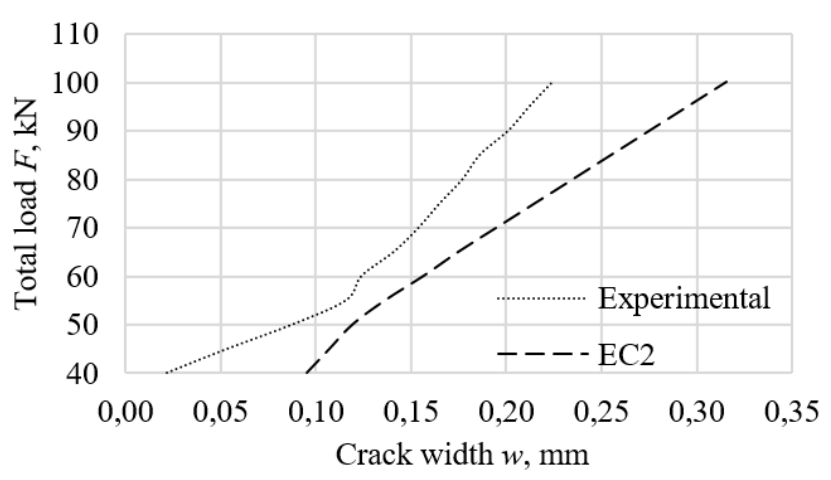

Fig. 18 Load-crack width curve of A2 series

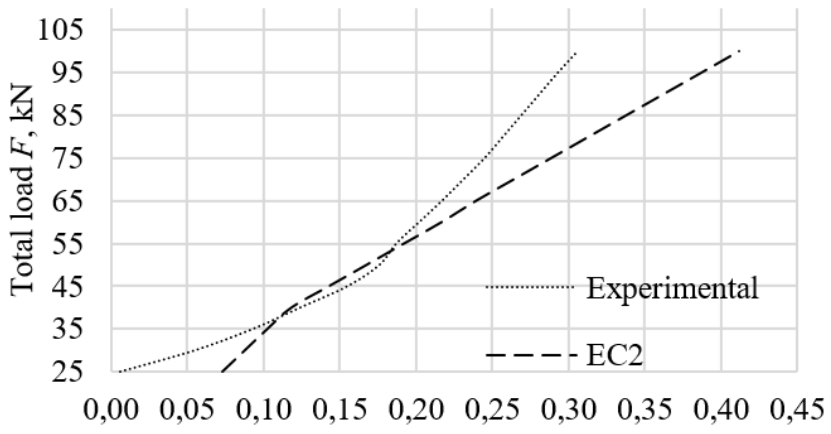

Crack width $w, \mathrm{~mm}$

Fig. 19 Load-crack width curve of A3 series

Curves of load-slip at the end of CFRP sheets between the concrete and CFRP of series 2 specimens are pre- 
sented in Fig. 20. Comparing the different beams, the smallest slip at the end of CFRP sheet was observed for C2 beam, at $100 \mathrm{kN}$ and higher load. It means that the biggest shear (bond) stress between concrete and CFRP at the same load is also in $\mathrm{C} 2$ beam, where the load bearing capacity is highest. The slip starts to increase rapidly $(100 \mu \mathrm{m}$ per $10-15 \mathrm{kN})$ when the load reaches $90 \mathrm{kN}$.

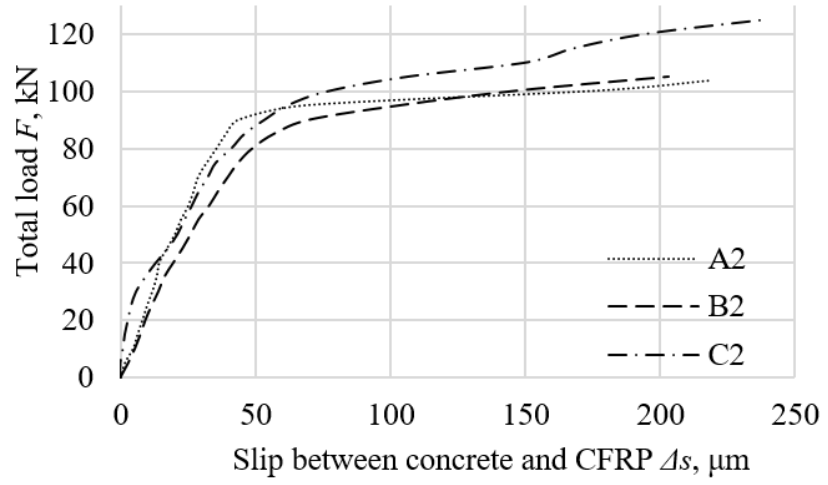

Fig. 20 Load- slip between CFRP and concrete curve of 2 series

\section{Conclusions}

1. Under the conditions of carried out experiments, the pre-cracking in composite beams has enhanced the flexural capacity and increased the stiffness in comparison to uncracked reinforced concrete beams strengthened with CFRP sheets.

2. Good agreement was found comparing experimental and theoretical (EC2) deflections of RC beams strengthened with CFRP. However, for more detailed verification, the analysis should be extended with more specimens.

3. The slip between concrete and CFRP at the end of CFRP sheet increases rapidly (100 $\mu \mathrm{m}$ per $10-15 \mathrm{kN})$ until reaching the maximum slip value, when reinforced concrete beam strengthened with CFRP is utilized $60-90 \%$ of its load bearing capacity.

\section{Acknowledgment}

The authors gratefully acknowledgment "DRIZORO" company for the support of CFRP and epoxy resins materials, also Šarūnas Kelpša for helping with the planning of the experiment.

\section{References}

1. Guo, J. D. 2003. Interfacial models for fiber reinforced polymer (FRP) sheets externally bonded to concrete.

2. Esfahani, M. R.; Kianoush, M. R.; Tajari, A. R. 2007. Flexural behaviour of reinforced concrete beams strengthened by CFRP sheets 29: 2428-2444. http://dx.doi.org/10.1016/j.engstruct.2006.12.008.

3. Triantafillou, T.; Matthys, S.; Audenaert, K.; Balázs, G.; Blaschko, M. and others. 2001. Externally bonded FRP reinforcement for RC structures, FIB Tech. Rep. Bull. 14(138).

4. Dias, S. J. E.; Barros, J. A. O.; Janwaen, W. 2018. Behavior of RC beams fl exurally strengthened with NSM CFRP laminates, Compos. Struct. 201: 363-376. http://dx.doi.org/10.1016/j.compstruct.2018.05.126.
5. Mirmiran, A.; Nanni, A. 2006. Composites in civil engineering, Int. Inst. FRP Constr. (IIFC), vol. 824.

6. Ism, M. M.; Rabie, M. 2019. Flexural behavior of continuous RC beams strengthened with externally bonded CFRP sheets, Alexandria Eng. J. 58(2): 789-800. http://dx.doi.org/10.1016/j.aej.2019.07.001.

7. Przemyslaw, B. 2019. Flexural behaviour of concrete beams reinforced with di ff erent grade steel and strengthened by CFRP strips 167: 411-421. http://dx.doi.org/10.1016/j.compositesb.2019.02.056.

8. Seracino, R. 2004. FRP Composites in civil engineering CICE 2004, vol. 1005.

9. Guo, Z. G.; Cao, S. Y.; Sun, W. M.; Lin, X. Y. 2005. Experimental study on bond stress-slip behaviour between FRP sheets and concrete, Proc. Int. Symp. Bond Behav. FRP Struct. 8: 77-84.

10. Nanni, A. and others. 1997. Behavior of precracked rc beams strengthened with carbon FRP sheets, 63-70 p.

11. Yu, F.; Zhou, H.; Jiang, N.; Fang, Y.; Song, J. and others. 2020. Flexural experiment and capacity investigation of CFRP repaired RC beams under heavy predamaged level, Constr. Build. Mater., vol. 230. http://dx.doi.org/10.1016/j.conbuildmat.2019.117030.

12. Adel, A.; Hamed, A.; El-kashif, K. F. O. 2019. Flexural strengthening of preloaded reinforced concrete continuous beams: An experimental investigation, Alexandria Eng. J. 58: 207-216.

http://dx.doi.org/10.1016/j.aej.2018.11.011.

13. Bsisu, K. A. 2017. The use of Hashin damage criteria, CFRP - concrete interface and concrete damage plasticity models in 3D finite element modeling of retrofitted reinforced concrete beams with CFRP sheets 14: 11711184. http://dx.doi.org/10.1007/s13369-016-2356-3.

14. Kishi, N.; Asce, M.; Zhang, G.; Mikami, H. 2014. Numerical cracking and debonding Analysis of RC beams reinforced with FRP numerical cracking and debonding analysis of RC beams reinforced with FRP sheet, vol. 9. http://dx.doi.org/10.1061/(ASCE)1090-0268(2005)9.

15. Camata, G.; Spacone, E.; Al-mahaidi, R.; Saouma, V. 2015. Analysis of test specimens for cohesive nearbond failure of fiber-reinforced analysis of test specimens for cohesive near-bond failure of fiber-reinforced polymer-plated concrete, J. Compos. Constr. 10: 528538. http://dx.doi.org/10.1061/(ASCE)1090-0268(2004)8.

16. Saadatmanesh, H.; Malek, A. M. 1998. Design guidelines for flexural strengtheningof RC Beams with FRP plates vol. 10:158-164.

17. Niu, H.; Wu, Z. 2006. Effects of FRP-concrete interface bond properties on the performance of RC beams strengthened in flexure with externally bonded FRP sheets, no. October, 723-731p.

18. David, E.; Ragneau, E. 2002. Finite element modelling of flexural behaviour of externally bonded CFRP reinforced concrete structures, Elsevier 7: 1423-1429. http://dx.doi.org/0141-0296/02/\$.

19. Rizkalla, S. H.; Bakis, C. E.; Balaguru, P. N.; Ballinger, C. A.; Bank, L. C. and others. 2002. Guide for the design and construction of externally bonded FRP systems for strengthening concrete structures reported by ACI committee 440, ACI Comm. 440.

20. Obaidat, Y. T.; Heyden, S.; Dahlblom, O. 2010. The effect of CFRP and CFRP, concrete interface models 
when modelling retrofitted RC beams with FEM, Compos. Struct. 92(6): 1391-1398.

http://dx.doi.org/10.1016/j.compstruct.2009.11.008.

21. Drizoro. Repair and strengthening system based on carbon fiber sheets, Tech. Bull., vol. 8 .

22. Schillo, N.; Taras, A.; Feldmann, M. 2018. Assessing the reliability of local buckling of plates for mild and high strength steels, J. Constr. Steel Res. 142: 86-98. http://dx.doi.org/10.1016/j.jcsr.2017.12.001.

23. Xiao, J.; Hou, Y.; Huang, Z. 2014. Beam test on bond behavior between high-grade rebar and high-strength concrete after elevated temperatures, Fire Saf. J. 69: 2335. http://dx.doi.org/10.1016/j.firesaf.2014.07.001.

24. Lai, B.; Liew, J. Y. R.; Hoang, A. Le 2019. Behavior of high strength concrete encased steel composite stub columns with C130 concrete and S690 steel, Eng. Struct. 200: 109743. http://dx.doi.org/10.1016/j.engstruct.2019.109743.

25. Qiang, Z.; Yaozhuang, L.; Lei, X.; Peiyuan, L. 2019. Bond strength and corrosion behavior of rebar embedded in straw ash concrete, Constr. Build. Mater. 205: 2130.

http://dx.doi.org/10.1016/j.conbuildmat.2019.01.228.

26. Somodi, B.; Kövesdi, B. 2017. Flexural buckling resistance of cold-formed HSS hollow section members, JCSR 128: 179-192. http://dx.doi.org/10.1016/j.jcsr.2016.08.014.

27. Somodi, B.; Kövesdi, B. 2018. Thin-walled structures residual stress measurements on welded square box sections using steel grades of S235 - S960, Thin Walled Struct. 123: 142-154. http://dx.doi.org/10.1016/j.tws.2017.11.028.

28. Beverly, P. 2010. fib Model Code for Structures 2010, vol. 428.

29. 2007. LST EN 1992-1-1. Eurokodas 2. Gelžbetoninių Konstrukcijų Projektavimas. 1-1 dalis.

30. Zadlauskas, S. 2013. The research on cracking and deformation of reinforced concrete bridges under static and dynamic loads, Doctoral dissertation, vol. 113.

31. Daugevičius, M. 2010. Influence of Long-Term Load on the Behaviour of Reinforced Concrete Beams Strengthened with Carbon Fibre Composite, Doctoral dissertation, vol. 150.

T. Lisauskas, M. Augonis, T. Zingaila, M.R.T. Arruda

STIFFNESS AND STRENGTH ANALYSIS OF FLEXURAL RC BEAMS STRENGTHENED WITH CFRP SHEETS CONSIDERING THE INFLUENCE OF PRE-CRACKING

\section{S u m m a r y}

This paper presents experimental, numerical and analytical analysis of newly cast and pre-cracked flexural reinforced concrete beams strengthened with CFRP. In total, 9 intermediate-scale composite beams were cast and tested using 4-point bending test setup. Midspan deflection, width of the cracks, concrete and CFRP strains were measured during the experimental program. Clear efficiency of composite pre-cracked beams was observed in comparison to newly cast beams: enhanced flexural capacity and increased stiffness after appearance of primary cracks in tension zone. Good agreement was found comparing experimental and theoretical (EC2) deflections of RC beams strengthened with CFRP. However, for more detailed verification, the analysis should be extended with more specimens. The shear stress at the end of CFRP sheets between the concrete and CFRP increased rapidly until reaching maximum slip value, when the reinforced concrete beam strengthened with CFRP reaches 60-90\% utilization of load bearing capacity. All experimental results were compared with numerical and analytical calculations. Experimental, numerical and analytical results were in sufficiently good agreement.

Keywords: CFRP, pre-cracks, ABAQUS, strengthening.

Received January 16, 2020

Accepted August 25, 2020 